\title{
Bragantia, v.72, n.3, 2013
}

Devido a um erro de editoração eletrônica, o artigo "Crescimento, composição mineral e fenóis totais de espécies de Passiflora em função de fontes nitrogenadas" necessita de correção no e-mail do autor correspondente.

Pág.247

Onde se lê:

simone@uenf.br

\section{Leia-se:}

msimone@uenf.br 